\title{
Androgen biosynthesis in castration-resistant prostate cancer
}

\author{
Trevor M Penning
}

Perelman School of Medicine, Center of Excellence in Environmental Toxicology, University of Pennsylvania, Philadelphia, Pennsylvania 19104-6084, USA

Correspondence should be addressed to T M Penning Email penning@upenn.edu

\begin{abstract}
Prostate cancer is the second leading cause of death in adult males in the USA. Recent advances have revealed that the fatal form of this cancer, known as castration-resistant prostate cancer (CRPC), remains hormonally driven despite castrate levels of circulating androgens. CRPC arises as the tumor undergoes adaptation to low levels of androgens by either synthesizing its own androgens (intratumoral androgens) or altering the androgen receptor (AR). This article reviews the major routes to testosterone and dihydrotestosterone synthesis in CRPC cells and examines the enzyme targets and progress in the development of isoform-specific inhibitors that could block intratumoral androgen biosynthesis. Because redundancy exists in these pathways, it is likely that inhibition of a single pathway will lead to upregulation of another so that drug resistance would be anticipated. Drugs that target multiple pathways or bifunctional agents that block intratumoral androgen biosynthesis and antagonize the AR offer the most promise. Optimal use of enzyme inhibitors or AR antagonists to ensure maximal benefits to CRPC patients will also require application of precision molecular medicine to determine whether a tumor in a particular patient will be responsive to these treatments either alone or in combination.
\end{abstract}

\section{Key Words}

- intratumoral androgen biosynthesis

- androgen receptor

- enzyme inhibitors

- androgen receptor antagonists

\section{Introduction}

The growth of the normal and abnormal prostate requires a source of androgens. This is evident in advanced prostate cancer as the early studies of Huggins and Hodges showed that surgical castration plus adrenalectomy leads to a remission of the disease (Huggins \& Hodges 1941, Huggins 1965). In addition, individuals with an inherited deficiency of steroid $5 \alpha$-reductase type 2 have completely atrophied prostates, indicating that $5 \alpha$-dihydrotestosterone (DHT) is the most important androgen for the development of prostate (Russell \& Wilson 1994). Based on these findings, androgen-deprivation therapy (ADT) has evolved to become a standard treatment of care for patients with localized advanced prostate cancer. ADT now includes the use of a LHRH agonist (e.g. leuprolide or goserelin) (Sharifi et al. 1996) and an androgen receptor (AR) antagonist (e.g. R-bicalutamide) (Kennealey \& Furr 1991). Following a period of relapse, the cancer often reappears, and this is accompanied by rising levels of serum prostate-specific antigen (PSA). PSA (KLK3) is an androgen-dependent gene, and increased expression of PSA in an environment of castrate levels of circulating androgens indicates that adaptive androgen signaling has emerged in the tumor. This form of the disease is known as castration-resistant prostate cancer (CRPC), which is almost uniformly fatal. The adaptive androgen signaling in CRPC cells can occur due to intratumoral androgen biosynthesis and/or changes in the AR, e.g. gene amplification, $A R$ somatic mutations, and splice variants 
that make the AR constitutively active (Knudsen \& Penning 2010). This review focuses on the androgen biosynthetic pathways that occur in CRPC cells, the enzyme targets, and their inhibition. It also discusses mechanisms of drug resistance to these agents.

\section{Pathways to testosterone and DHT synthesis}

In individuals with an intact testis, circulating testosterone is the immediate precursor of DHT in the prostate. This leads to the proposal that in CRPC cells the dominant route to DHT synthesis is via the classical pathway (Fig. 1). In this pathway, DHEA of adrenal origin is converted to $\Delta^{4}$-androstene-3, 17-dione via $3 \beta$-hydroxysteroid dehydrogenase/ketosteroid isomerase (HSD3B1), which is then reduced to testosterone by one or more $17 \beta$-HSD isoforms. Testosterone is then reduced to DHT by steroid $5 \alpha$ reductase type 1 or 2 (SRD5A1 or SRD5A2); i.e., the route is DHEA $\rightarrow \Delta^{4}-\mathrm{AD} \rightarrow$ testosterone $\rightarrow$ DHT. Recent studies in a variety of prostate cancer cell lines have shown that this pathway may not exist and that $\Delta^{4}$-AD is reduced by $5 \alpha$ reductase directly to $5 \alpha$-androstane-3, 17 -dione (Adione), which is subsequently reduced to DHT by $17 \beta$-HSD. As this pathway bypasses testosterone formation altogether, it is known as the alternative pathway; i.e., the route is DHEA $\rightarrow \Delta^{4}$-AD $\rightarrow$ Adione $\rightarrow$ DHT (Chang et al. 2011). Other studies in the tammar wallaby and on the maturation of genitalia in human neonates have demonstrated the existence of a third pathway to DHT synthesis
(Wilson et al. 2003, Auchus 2004, Shaw et al. 2006, Fluck et al. 2011, Auchus \& Miller 2012). In this pathway, reduction of the A-ring of the steroid occurs at the level of C21 steroids. Pregnenolone is converted to progesterone (Prog) by $3 \beta-H S D$, which is subsequently reduced to $5 \alpha$-dihydroprogesterone (DHP) by $5 \alpha$-reductase. DHP is converted by $3 \alpha$-HSD to allopregnanolone ( $3 \alpha$-hydroxy$5 \alpha$-pregnane-20-one), which then acts as a substrate for cytochrome P450 17A1 (CYP17A1) (17 $\alpha$-hydroxylase/ 17,20 -lyase) to produce androsterone. Androsterone is then reduced by $17 \beta$-HSD to yield $3 \alpha$-androstanediol ( $3 \alpha$-Adiol), which is oxidized to yield DHT by $3 \alpha$-HSD; i.e., the route is $\operatorname{Prog} \rightarrow \mathrm{DHP} \rightarrow$ allopregnanolone $\rightarrow$ androsterone $\rightarrow 3 \alpha$-Adiol $\rightarrow$ DHT. This pathway is known as the 'backdoor pathway' (Wilson et al. 2003, Auchus 2004, Shaw et al. 2006, Fluck et al. 2011, Auchus \& Miller 2012). The field has now advanced so that the discrete $17 \beta-H S D$ and $3 \alpha$-HSD isoforms involved in these interconversions are known, and these are discussed below.

\section{Enzyme targets and their inhibition}

P450 17 $\alpha$-hydroxylase/17, 20-lyase, P450 17A1 (CYP17A1)

In pathways to intratumoral androgen synthesis in castrated males, there could either be a dependency on adrenal steroids (DHEA and DHEA-SO $\mathrm{S}_{4}$ ) or a dependency on de novo synthesis of androgens from cholesterol within the prostate. The major precursors for androgen

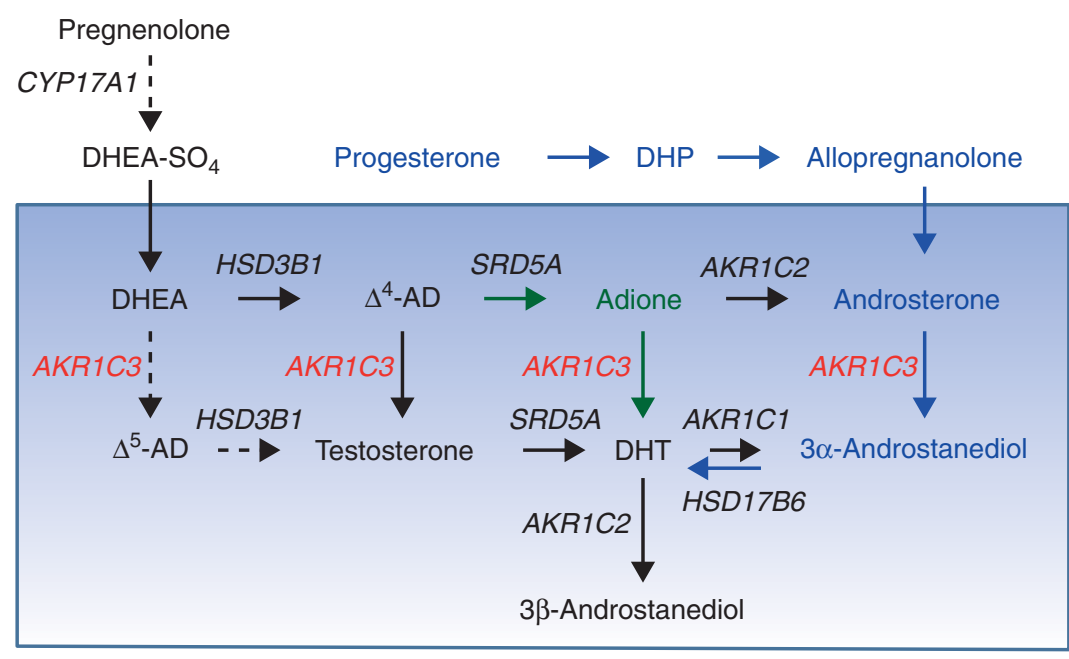

\section{Figure 1}

Androgen biosynthesis in prostate cancer cells. Reactions in the blue rectangle are known to occur in the prostate. Names of genes (in italics) that code for the various enzymes are shown. The classical pathway to
DHT synthesis is indicated by black arrows, the alternative pathway to DHT synthesis is indicated by green arrows, and the backdoor pathway to DHT synthesis is indicated by blue arrows.

Published by Bioscientifica Ltd. 
biosynthesis in CRPC patients are likely to be DHEA and DHES-SO ${ }_{4}$ of adrenal origin, in these patients circulating levels are of the order of 200 and $200000 \mathrm{ng} / \mathrm{dl}$ respectively. In contrast, the circulating levels of testosterone are less than $10 \mathrm{ng} / \mathrm{dl}$ (Tamae et al. 2013). It is difficult to imagine that prostate tumors could achieve this level of DHEA synthesis. The conversion of pregnenolone to DHEA in the adrenal is catalyzed by P450 17A 1 , which is a bifunctional enzyme catalyzing $17 \alpha$-hydroxylation of the steroid side chain followed by acyl-carbon-bond cleavage via its 17, 20-lyase activity (Nakajin \& Hall 1981, Nakajin et al. 1981, Chung et al. 1987). This enzyme is inhibited by abiraterone acetate $\left(\right.$ Zytiga $\left.^{\mathrm{R}}\right)$, which has recently been approved by the FDA for the treatment of CRPC patients, who have been shown to be unresponsive to the taxanes (e.g. docetaxel) (Attard et al. 2009, 2012; Table 1). The disadvantage of this approach is that in the absence of P450 17A1 the adrenal can no longer synthesize cortisol. This leads to compensatory increases in the production of ACTH in the anterior pituitary and elevated production of the potent mineralocorticoid desoxycorticosterone in the adrenal, which can lead to life-threatening hypertension (Attard et al. 2012). This side effect is eliminated by the co-administration of a synthetic glucocorticoid, e.g. prednisone. Because prednisone suppresses the adrenal-pituitary axes, the issue of whether prednisone by itself would be effective in limiting adrenal DHEA production arises. Due to this, second-generation P450 17A1 inhibitors exhibiting a preference for inhibiting only the 17, 20-lyase VT-464 have been developed (Abbott et al. 2012). In addition, other P450 17A1 inhibitors that also enhance AR degradation, e.g. galeterone (TOK001), have been developed (Njar \& Brodie 1999, Bruno et al. 2008). Each of these P450 17A1 inhibitors is steroid-based and possesses a heterocycle at the $17 \beta$-position, which creates a sixth ligand for the heme moiety of the P450. The availability of the P450 17A1 crystal structure will aid in the development of superior agents that may only inhibit the lyase step (DeVore \& Scott 2012). Currently, abiraterone acetate is used in the standard treatment of care for CRPC patients.

The clinical success of abiraterone has also led to its use in clinical trials in the neoadjuvant setting as a possible first-line agent in ADT. In a recent clinical trial that compared leuprolide alone with leuprolide plus abiraterone, only the abiraterone arm was found to lead to a significant $>90 \%$ reduction in serum testosterone, DHEA, and DHEA-SO ${ }_{4}$ levels as might be expected (Taplin et al. 2014). However, the levels of DHEA-SO $(20000 \mathrm{ng} / \mathrm{dl})$ that still remained represented a significant reservoir of androgen precursor, assuming that prostate cancer patients have appropriate levels of the organic anionic transporters and steroid sulfatase (STS). If this reservoir of DHEA-SO ${ }_{4}$ is bioavailable, it can be assumed that other agents targeting P450 17A1 would have the same profile.

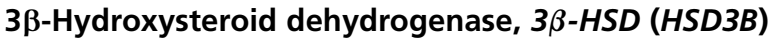

$3 \beta$-HSD is a bifunctional $\mathrm{NAD}^{+}$-dependent enzyme that converts DHEA to $\Delta^{4}$-AD in the prostate (Luu The et al. 1989, Rheaume et al. 1991, Labrie et al. 1992, Lachance et al. 1992). There are two isoforms of this enzyme that are encoded by distinct genes, but these are closely related, structurally, functionally, and kinetically (HSD3B1 and HSD3B2) (Thomas et al. 2002a). The 3 $\beta$-HSD type 1 enzyme is the isoform that is dominantly expressed in prostate cancer cells. Traditionally, the $3 \beta$-HSD type 2 enzyme (found in the gonads and adrenals) was thought to be a poor drug target as it introduces the

Table 1 Drugs that block intratumoral androgen biosynthesis

\begin{tabular}{|c|c|c|}
\hline Target enzyme & Gene & Drug \\
\hline P450 17A1 & CYP17A1 & $\begin{array}{l}\text { Abiraterone acetate } \\
\text { Galeterone (TOK001) } \\
\text { Orteronel }\end{array}$ \\
\hline Steroid $5 \alpha$-reductase & $S R D 5 A 1$ and $S R D 5 A 2$ & $\begin{array}{l}\text { Finasteride } \\
\text { Dutasteride } \\
\text { Epristeride }\end{array}$ \\
\hline 3ß-HSD type 1 & HSD3B1 & $\begin{array}{l}\text { Trilostane } \\
\text { Epostane }\end{array}$ \\
\hline AKR1C3 (type 5 17 $\beta$-HSD) & $A K R 1 C 3$ & $\begin{array}{l}\text { Indomethacin } \\
\text { GTX-560 } \\
\text { Astellas ASP9521 }\end{array}$ \\
\hline Steroid sulfatase & STS & 667-Coumate (STX64, Irosustat) \\
\hline
\end{tabular}

Properties
Competitive inhibitors that may
require co-administration with
prednisone
Mechanism-based inhibitor
Mechanism-based inhibitor
Non-competitive inhibitor
Competitive inhibitor
Competitive inhibitor
Competitive inhibitor
Competitive inhibitor
Competitive inhibitor
Irreversible inhibitor

http://erc.endocrinology-journals.org DOI: 10.1530/ERC-14-0109
(C) 2014 Society for Endocrinology Printed in Great Britain
Published by Bioscientifica Ltd. 
$\Delta^{4}$-3-ketosteroid functionality, present in androgens, progestins, glucocorticoids, and mineralocorticoids, and thus the inhibition of this enzyme would block the production of most steroid hormones. Inherited deficiencies of $3 \beta$-HSD type 2 provide a view of the phenotype that enzyme inhibition would cause, and this can lead to low, moderate, and severe salt wasting (Rheaume et al. 1992, 1994). This raises the issue of whether it is possible to discriminate between the two enzyme forms with inhibitors (Thomas et al. 2002b). Compounds such as epostane and trilostane exhibit a 13- to 16-fold preference for the inhibition of the type 1 enzyme, but this difference is unlikely to be sufficient to be of clinical utility (Thomas et al. 2008). Interestingly, abiraterone is a substrate for $3 \beta$-HSD type 1 and the enzyme-generated product containing the $\Delta^{4}$-3-ketosteroid functionality is a reasonably potent inhibitor (Li et al. 2012). It is unclear whether this mode of action contributes to the clinical efficacy of abiraterone. Recently, a unique gain-in-function somatic mutation has been identified in 3 $\beta$-HSD type 1 in CRPC patients (Chang et al. 2013). This gain-in-function mutation did not alter the steady-state kinetic parameters ( $K_{\mathrm{m}}$ and $V_{\max }$ ) of the enzyme, but it increased its stability by preventing ubiquitination and proteasome degradation of the enzyme. These intriguing observations indicate that somatic mutations in other enzymes involved in the androgen metabolic pathway may be selected as an adaptation to androgen deprivation, but these are yet to be identified.

\section{$5 \alpha$-Reductase types 1, 2, and 3 (SRD5A1, SRD5A2, and SRD5A3)}

Deficiency of $5 \alpha$-reductase type 2 (SRD5A2) results in an atrophied prostate (Russell \& Wilson 1994), and this has led to the development of inhibitors of the enzyme, such as finasteride, which is effective in the treatment of benign prostatic hyperplasia (BPH) patients (Bartsch et al. 2002). However, treatment of $\mathrm{BPH}$ patients with finasteride does not result in complete reduction of DHT levels in the prostate, and this has led to the development of bifunctional agents that could target $5 \alpha$-reductase type 1 and type 2, e.g. dutasteride (Frye 2006). Transcript profiling of CRPC patients revealed that there was a change in the ratio of expression of the two isoforms that favored $5 \alpha$-reductase type 1 (Stanbrough et al. 2006), indicating that compounds such as dutasteride might be preferred to block intratumoral androgens in patients with advanced prostate cancer. Clinical trials on the chemoprevention properties of finasteride or dutasteride yielded the same outcome (Thompson et al. 2003, Andriole et al. 2010). The trials demonstrated that although there was a reduction in tumor incidence in a subset of patients, a more aggressive form of the cancer appeared. These results have led to controversy as to whether the detection of the more aggressive tumors was due to the frequency of biopsy and biopsy bias in the trials. Because of these data, both finasteride and dutasteride are not approved by the FDA for the treatment of prostate cancer patients and there is a warning label for this indication (U.S. Food and Drug Administration 2011). Explanations for these data could also include accumulation of testosterone in the presence of $5 \alpha$-reductase inhibition, accumulation of DHT precursors that might activate a mutant $\mathrm{AR}$, or the appearance of a third form of $5 \alpha$-reductase (SRD5A3) (Uemura et al. 2008, Titus et al. 2014). 5 $\alpha$-Reductase type 3 may not play such an important role in intratumoral androgen biosynthesis, as it is predominately involved in polyprenol biosynthesis (Cantagrel et al. 2010).

Finasteride and dutasteride are steroid-based competitive inhibitors of $5 \alpha$-reductase that were developed out of consideration of the transition-state analogs for the enzyme. Each of these compounds can give rise to the enolate intermediate proposed for the enzyme-catalyzed reaction. Subsequently, finasteride has been found to be a mechanism-based inactivator of $5 \alpha$-reductase type 2 . In this mechanism, finasteride is reduced to dihydrofinasteride, which reacts with $\mathrm{NADP}^{+}$to form a bisubstrate analog with a $K_{\mathrm{i}}$ of $10^{-13} \mathrm{M}$ (Bull et al. 1996). Slow hydrolysis of the analog releases dihydrofinasteride into solution. It is likely that dutasteride works via the same mechanism.

Other $5 \alpha$-reductase inhibitors have been developed, e.g. epristeride from Smith, Kline and French. These compounds are acrylate-based, mimic the enolate reaction intermediate, and act as uncompetitive inhibitors by forming E.NADP ${ }^{+}$inhibitor complexes in the ordered bi-bi kinetic mechanism (Levy et al. 1994).

\section{Aldo-ketoreductases (AKRs): AKR1C1, AKR1C2, and AKR1C3}

AKR1C1, AKR1C2, and AKR1C3 are NADPH-dependent monomeric cytosolic ketosteroid reductases (Penning et al. 2000) that play pivotal roles in steroidogenesis in the human prostate (Table 2; Rizner et al. 2003, Lin et al. 2004, Bauman et al. 2006a, Fung et al. 2006). These enzymes have different ratios of 3-, 17-, and 20-ketosteroid reductase activity (Rizner \& Penning 2013). In vitro, AKR enzymes act as hydroxysteroid dehydrogenases. However, in mammalian cell transfection studies, in which the

Published by Bioscientifica Ltd. 
prevailing concentration of $\mathrm{NAD}(\mathrm{P})(\mathrm{H})$ must be used, these enzymes function only as NADPH-dependent reductases (Rizner et al. 2003). This is due to their nanomolar potency for NADPH and the inhibition of the $\mathrm{NAD}^{+}$-dependent oxidation reactions by low micromolar concentrations of NADPH (Rizner et al. 2003). In androgen metabolism, AKR1C 1 acts predominately as a $3 \beta-\mathrm{HSD}$ and reduces DHT to $5 \alpha$-androstane- $3 \beta, 17 \beta$-diol (3$\beta$-Adiol) (Steckelbroeck et al. 2004). 3 $\beta$-Adiol is an inactive androgen, but a potent agonist of ER $\beta$, which would be an anti-proliferative signal in prostate cancer cells (Guerini et al. 2005). AKR1C2 acts predominately as a $3 \alpha$-HSD and converts DHT $\left(K_{\mathrm{d}}=10^{-11} \mathrm{M}\right.$ for the AR) to $5 \alpha$-androstane- $3 \alpha, 17 \beta$-diol ( $3 \alpha$-Adiol, $\mathrm{K}_{\mathrm{d}}=10^{-6} \mathrm{M}$ for the AR) effectively terminating androgen action (Jin \& Penning 2006). The role of AKR1C2 was recapitulated in transfection studies in LNCaP and PC-3 cells (Rizner et al. 2003).

AKR1C3 (also known as 17 $\beta$-HSD type 5) is perhaps the most important AKR1C isoform in CRPC patients (Fig. 1). AKR1C3 was originally cloned from a human prostate cDNA library and was found to be overexpressed in prostate cancer cells (Lin et al. 1997, Fung et al. 2006). AKR1C3 catalyzes the NADPH-dependent reduction of $\Delta^{4}$-AD to testosterone, the reduction of Adione to DHT, and the reduction of androsterone to 3 $\alpha$-Adiol (Lin et al. 1997, Penning et al. 2000). Thus, all key steps in the classical, alternative, and backdoor pathways to DHT synthesis proceed through AKR1C3. In LNCaP-AKR1C3 cells, $\Delta^{4}$-AD is robustly converted to testosterone-17 $\beta$-glucuronide
(Byrns et al. 2012). AKR1C3 is necessary and sufficient to cause androgen-dependent gene expression in prostate cancer cell lines and in xenografts. For example, the gene expression of PSA and TMPSSERG is increased in the presence of the AKR1C3 substrate $\Delta^{4}$-AD, and this effect is blocked by AKR1C3 short hairpin RNA (shRNA) and the AKR1C3 isoform-specific inhibitor indomethacin in VCaP cells (Cai et al. 2011). AKR1C3 is also overexpressed in response to $\mathrm{ADT}$ in prostate cancer patients. This is observed in prostate cancer cell lines maintained in androgen-deprived media, in xenograft models of CRPC, and in CRPC patients (Hofland et al. 2010, Pfeiffer et al. 2011, Hamid et al. 2012, Mitsiades et al. 2012). Compelling evidence that AKR1C3 is overexpressed in CRPC patients has been obtained using Affymetrix microarray, qPCR, and immunohistochemistry (Stanbrough et al. 2006). It is also overexpressed in soft-tissue metastasis in CRPC patients (Stanbrough et al. 2006). Measurements of intratumoral androgen levels also support the involvement of AKR1C3 in prostate cancer steroidogenesis. A 30-fold increase in the ratio of testosterone:DHT over that observed in prostate cancer cells was found in soft-tissue metastasis, indicating that the tumor is more dependent on testosterone than on DHT and that the source of androgen is probably AKR1C3 (Montgomery et al. 2008). The buildup of testosterone in these patients would be contrary to the findings of Chang et al. (2011), who showed that the pathway to DHT synthesis bypasses testosterone formation altogether. These findings may be reconciled

Table 2 Hydroxysteroid dehydrogenases expressed in the human prostate

\begin{tabular}{|c|c|c|}
\hline Enzyme & Gene & Chromosome \\
\hline 3ß-HSD type 1 & HSD3B1 & $1 \mathrm{p} 13.1$ \\
\hline $\begin{array}{l}\text { AKR1C1 } \\
3 \alpha-H S D \text { type } 1 \\
20 \alpha(3 \alpha) \text {-HSD }\end{array}$ & $A K R 1 C 1$ & 10p15-p14 \\
\hline $\begin{array}{l}\text { AKR1C2 } \\
3 \alpha \text {-HSD type } 3\end{array}$ & $A K R 1 C 2$ & 10p15-p14 \\
\hline $\begin{array}{l}\text { AKR1C3 } \\
17 \beta-H S D \text { type } 5 \text { and } \\
3 \alpha-H S D \text { type } 2\end{array}$ & $A K R 1 C 3$ & 10p15-p14 \\
\hline $17 \beta$-HSD type 2 & HSD17B2 & $16 q 24.1-q 24.2$ \\
\hline 17ß-HSD type 3 & HSD17B3 & $9 q 22$ \\
\hline 17ß-HSD type 4 & HSD17B4 & $5 q 21$ \\
\hline $\begin{array}{l}\text { 17 } \beta \text {-HSD type } 6 \\
\text { RL-HSD }\end{array}$ & HSD17B6 & $12 q 13$ \\
\hline
\end{tabular}

Reaction catalyzed in the prostate

DHEA to $\Delta^{4}-A D$

$\Delta^{5}$-Androstene-3 $\beta, 17 \beta$-diol to testosterone DHT to $3 \beta$-Adiol

DHT to $3 \alpha$-Adiol

$\Delta^{4}$-AD to testosterone

$5 \alpha$-Adione to DHT

Androsterone to $3 \alpha$-Adiol

Testosterone to $\Delta^{4}-A D$

DHT to Adione

$\Delta^{4}$-AD to testosterone

DHT to Adione

Testosterone to $\Delta^{4}-A D$

DHT to Adione

$3 \alpha$-Adiol to DHT

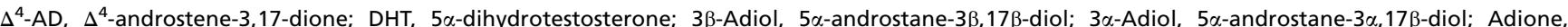
$5 \alpha$-androstane-3,17-dione.

http://erc.endocrinology-journals.org DOI: 10.1530/ERC-14-0109
C 2014 Society for Endocrinology Printed in Great Britain
Published by Bioscientifica Ltd. 
if the pathway to DHT synthesis that dominates in CRPC patients is patient-dependent. Interestingly, in the studies of Chang et al. (2011) in which $\Delta^{4}$-AD was used as a precursor, a large buildup of Adione was observed, indicating that AKR1C3 may catalyze the ratedetermining step in the conversion of Adione to DHT. Thus, AKR1C3 appears to be involved in androgen biosynthesis in the prostate irrespective of the pathway involved and may also be rate-determining. These findings have led to a spectrum of AKR1C3 inhibitors being developed both in academia and in industry. Astellas Pharmaceuticals and GTx have both developed AKRC13 inhibitors (Astellas Pharmaceuticals 2013, Watanabe et al. 2013, Yepuru et al. 2013).

The key to the development of AKR1C3 inhibitors is specificity and potency. AKR1C3 inhibitors should not inhibit AKR1C1 and AKR1C2 as these inactivate DHT and this would be counterproductive (see above). This creates an immediate challenge as AKR1C1, AKR1C2, and AKR1C3 have over $86 \%$ sequence identity and share similar $(\alpha / \beta)_{8}$-barrel crystal structures (Jin et al. 2001, Lovering et al. 2004). Nevertheless, our laboratory has been successful in developing AKR1C3 inhibitors based on three different chemical scaffolds that have midnanomolar inhibitory potency and the desired isoform selectivity. Each of these scaffolds was developed based on a compound screen that identified classes of nonsteroidal anti-inflammatory drugs as potential AKR1C3 inhibitors. Class I agents are based on $\mathrm{N}$-phenylaminobenozates, which are derivatives of $\mathrm{N}$-phenylanthranilates (e.g. flufenamic acid) (Adeniji et al. 2012). Class 2 agents are based on $\mathrm{N}$-naphthylaminobenzoates, which have the unusual property of inhibiting AKR1C3 with nanomolar potency, having > 200-fold selectivity, but also act as AR antagonists (Chen et al. 2012). Class 3 agents are based on indomethacin. Within the indomethacin series, three types of compounds were developed, one set based on indomethacin; another set in which the 2 '-methyl group of indomethacin was removed, the compounds of which are referred to as des-methyl indomethacin analogs; and the last set in which the carboxylic acid side chain at the $3^{\prime}$-position of the indole ring was switched with $2^{\prime}$-alkyl group, the compounds of which are referred to as $3^{\prime}$-alkyl analogs (Liedtke et al. 2013). Lead agents from all the three classes were counterscreened against COX1 and COX2 and were found to be devoid of inhibitory properties against these enzymes.

Crystal structures of the AKR1C3 inhibitor complexes provide a rationale as to why the agents developed do not inhibit AKR1C1 or AKR1C2 (Jin et al. 2001, Lovering et al. 2004, Chen et al. 2012, Flanagan et al. 2012, Liedtke et al. 2013). Unique subpockets (SP1, SP2, and SP3) into which different portions of the drug molecules bind were identified. These subpockets are either absent or of a smaller size in AKR1C1 and AKR1C2 (Byrns et al. 2011).

Further proof-of-principle studies have been carried out by GTx and Astellas Pharmaceuticals, both of which have their own AKR1C3 inhibitor programs. GTx-560 was found not only to inhibit AKR1C3 competitively, but also to be built out of a selective AR modulator program. Interestingly, GTx-560 was used as a tool to show that AKR1C3 also worked as a coactivator of the AR in HEK293 cells and this function was blocked by competitive inhibition of the enzyme by GTx-560 (Yepuru et al. 2013). Thus, AKR1C3 competitive inhibitors may have the hidden property of blocking AR coactivation. GTX-560 and the Astellas compound ASP9521 were found to inhibit the growth of CRPC tumors in xenograft models. Importantly, ASP9521 was the first AKR1C3-specific inhibitor to be used in human trials, but the phase I/II clinical trial was halted because despite being well tolerated, the drug was not clinically beneficial to the small number of CRPC patients in the trial. Importantly, no molecular pathology was performed on tumor biopsies of these patients to determine that AKR1C3 was overexpressed in the first place (Loriot et al. 2014).

\section{Other 17 $\beta$-HSD isoforms (HSD17B2, HSD17B3, HSD17B4, and HSD17B6)}

$17 \beta$-HSD isoforms that belong to the short-chain dehydrogenase/reductase (SDR) family also play important roles in androgen biosynthesis and metabolism in the prostate (Castagnetta et al. 1997). 17 $\beta$-HSD type 2 (HSD17B2) (Andersson et al. 1995) and 17 $\beta$-HSD type 4 (HSD17B4) (Adamski et al. 1995, Carstensen et al. 1996) are predominately $\mathrm{NAD}^{+}$-dependent dehydrogenases that inactivate testosterone and DHT by forming $\Delta^{4}$-AD and Adione respectively. Both are expressed in the human prostate and in prostate cancer patients (Castagnetta et al. 1997). 17 $\beta$-HSD type 3 (HSD17B3) converts $\Delta^{4}$-AD to testosterone; however, this enzyme is predominately Leydig cell-specific and mutations in this enzyme are associated with pseudohermaphroditism (Geissler et al. 1994). Although present in the prostate, its expression level is 1000- to 10 000-fold less than that of AKR1C3 and it is unlikely to play an important role in testosterone production, unless upregulated (R Mindnich \& TM Penning, 2012, unpublished observations). Inhibitors of

Published by Bioscientifica Ltd. 
$17 \beta$-HSD type 3 have been developed with the promise that they may be superior agents to leuprolide for causing chemical castration (Day et al. 2009, Vicker et al. 2009). $17 \beta$-HSD type 6 (HSD17B6) is in fact predominately a $3 \alpha$-HSD that converts $3 \alpha$-Adiol back to DHT (Bauman et al. 2006b). Earlier work carried out in this laboratory revealed all human $3 \alpha$-HSD isoforms to be capable of catalyzing this oxidation reaction using IRES-transfection constructs so that activity could be normalized against $\beta$-galactosidase in COS- 1 cells. This was coupled with expression studies and $A R$ reporter gene assays to determine which isoform could activate the AR, starting with $3 \alpha$-Adiol. Data unequivocally revealed $17 \beta$-HSD type 6 to be the major oxidative $3 \alpha$-HSD required for the conversion of $3 \alpha$-Adiol to DHT when compared with all the other candidate $3 \alpha-H S D$ genes (Bauman et al. 2006a). This work was validated by results from subsequent studies, which demonstrated that 17ß-HSD type 6 is the major oxidative enzyme in the 'backdoor pathway' in prostate cancer cell lines and xenografts (Mohler et al. 2011). These findings will probably lead to the emergence of inhibitor programs for $17 \beta$-HSD type 6 .

\section{Steroid sulfatase}

There is only one STS enzyme, formerly known as arylsulfatase C, and it is endcoded by the STS gene (Yen et al. 1987). This enzyme is required to cleave DHEA-SO of adrenal origin to produce free DHEA for prostate steroidogenesis. STS has been detected in prostate tissues by a number of investigators, and it can be inhibited by aryl sulfamates including 667COUMATE (STX64, Irosustat) and other compounds (Purohit et al. 1995, 1996). However, it should not be forgotten that STS deficiency is associated with $\mathrm{X}$-linked ichthyosis, a scalyskin disease affecting roughly 1 in every 2000-6000 males (Shapiro 1979, 1985), and would be an expected phenotype of chronic sulfatase inhibition in which cholesterol can no longer be mobilized from cholesterol sulfate.

\section{Uridine glucuronsyl transferases}

Uridine glucuronsyl transferases (UGTs) are major enzymes that catalyze the conjugation of hydroxyandrogens with UDP-glucuronic acid for elimination from the prostate. Some prostate cancer cell lines have very high UGT activity; e.g. in LNCaP cells, the major isoforms involved appear to be UGT2B15 and UGT2B17 (Guillemette et al. 1997). These isoforms are upregulated by ADT and by AR antagonists (Grosse et al. 2013). Studies carried out by the Plymate group revealed that during the progression to CRPC, there is not only increased expression of constitutively active $A R$ splice variants but also overexpression of UGTs (Hu et al. 2012). This indicated that increased UGT expression is part of an adaptive response of the tumor to become androgenindependent. In other studies, 526 Caucasian and 320 Asian men who underwent radical prostatectomy for clinically localized prostate cancer were examined for deletions in UGT2B genes. The relationship between genotypes and biochemical recurrence was assessed with multivariate Cox proportional hazard models. Plasma steroid levels were measured using specific and sensitive mass-spectrometry-based methods. These studies demonstrated that at least two deleted copies of UGT2B17 and UGT2B28 genes resulted in a hazard ratio of 2.26 for increased prostate cancer incidence (Nadeau et al. 2011).

\section{Clinical efficacy and mechanisms of drug resistance}

The clinical efficacy of drugs that target steroidogenic enzymes to disrupt the androgen axis can be determined by measuring the reduction in serum and intraprostatic androgen levels; measuring the reduction in serum PSA levels; measuring the intraprostatic levels of androgenregulated genes in tissue biopsies; and by correlation of serum drug levels with tissue drug levels. Stable-isotope dilution liquid chromatography-tandem mass spectrometry represents the state-of-the-art approach to measure serum and tissue androgen levels (Tamae et al. 2013). No single method can measure the levels of all the androgens of interest as the required sensitivity in the $0.1-1.0 \mathrm{pg}$ range requires steroid derivatization. Ketoandrogens can be derivatized as oximes with Girard-T (Tamae et al. 2013), while hydroxyandrogens have to be measured as picolinates (Higashi et al. 2005, 2006). Even with these methods, there is a need to measure both conjugated and free steroids, which requires additional digestion steps with $\beta$-glucuronidase and sulfatase. Measurement of a declining PSA level and its rebound could represent a measurement of drug response and relapse in the tumor respectively. However, if there is an intact prostate with underlying $\mathrm{BPH}$, this could be an important confounder that will influence PSA measurements. Measurement of drug levels in serum and tissue will help in the determination of whether effective drug concentrations have been attained, but could be confounded if drug metabolites that are also enzyme

Published by Bioscientifica Ltd. 
inhibitors are present. With at least three different pathways to DHT synthesis, this built-in redundancy could be blocked with dual steroid $5 \alpha$-reductase type 1 and type 2 inhibitors. However, the classical pathway to DHT synthesis could compensate, leading to a build-up of testosterone. With this redundancy, it is predicted that acquired drug resistance may occur. The one exception may be in the targeting of AKR1C3, which will not only inhibit all the pathways to DHT synthesis but also block testosterone formation.

Abiraterone effectively causes tumor remission in CRPC patients and prolongs survival by 3-4 months. Reasons for therapeutic failure could be the following: i) incomplete blockade of DHEA and DHEA-SO ${ }_{4}$ formation in the adrenal; ii) overexpression of P450 17A1; iii) overexpression of AKR1C3; iv) $A R$ gene amplification, and v) the emergence of $A R$ splice variants that are constitutively active without hormone (Cai et al. 2011, Mostaghel et al. 2011). These observations indicate that molecular profiling of the tumor should be performed before a drug is administered so that the correct target is blocked. For example, if constitutively active $A R$ splice variants are present, the administration of agents to block P450 17A1 would be futile.

\section{Eradication of the androgen axis}

Because of the adaptive responses that can occur with ADT, there has been excitement about the introduction of the AR superantagonist enzalutamide $\left(\mathrm{Xtandi}^{\mathrm{R}}\right)($ Tran et al. 2009, Scher et al. 2010, 2012). As might be predicted, enzalutamide also causes remission followed by the emergence of resistance. Thus, there are now clinical trials planned in which combination therapy of abiraterone and enzalutamide will be given together. Instead of combination therapy, there is hope that some of the new agents will be bifunctional and block intraprostatic androgen synthesis and the AR. Galeterone has this property; it is both a P450 17A1 inhibitor and will cause degradation of the AR simultaneously (Vasaitis et al. 2008). The $N$-naphthylaminobenzoate BMT4-158 is a 'first-in-class' bifunctional AKR1C3 inhibitor and an AR antagonist. BMT4-158 will inhibit AKR1C3 with an $\mathrm{IC}_{50}$ value of $50 \mathrm{nM}$, and it will block the conversion of $\Delta^{4}$-AD to testosterone and $\Delta^{4}$-AD-stimulated PSA production in LNCaP-AKR1C3 transfected cells. BMT4-158 will also block DHT-driven reporter gene activity with an $\mathrm{IC}_{50}$ value of $5.0 \mu \mathrm{M}$ and displace $\left[{ }^{3} \mathrm{H}\right]-\mathrm{R} 1881$ binding to the AR competitively.
Importantly, it will cause degradation of the AR in the presence and absence of DHT (Chen et al. 2012).

\section{Future considerations}

Advanced prostate cancer and CRPC remain hormonally driven, and inhibitors that block enzymes involved in intratumoral androgen biosynthesis in the castrate environment offer a therapeutic strategy. Redundancy in the pathways to DHT synthesis indicates that in many cases drug resistance may occur through bypass of one pathway. This can be surmounted by targeting enzymes required for all the pathways to testosterone and DHT synthesis. One enzyme of particular promise in this regard is AKR1C3. However, the tumor can also undergo adaptive AR signaling, indicating that eradication of the androgen axis may require bifunctional agents that block both enzymatic synthesis of androgens and AR signaling.

\section{Declaration of interest}

The author is the founder of Penzymes, LLC, which develops selective intracrine modulators to block the local synthesis of hormones in prostate, breast, and endometrial cancers.

\section{Funding}

This work was supported in part by grant numbers 1R01-DK47015, 1R01CA90744, P01-CA163227-01A1, and P30-ES013508 awarded to T M Penning.

\section{References}

Abbott D, Einser JR, Bird IM, Raffrety SW, Moore WR \& Schotzinger RJ 2012 Plasma steroid concentrations in male rhesus monkeys following treatment with the P450c17 (CYP) inhibitors VT-464 and abiraterone acetate. A comparison to human 17,20-lyase (lyase) and combined lyase/17 $\alpha$-hydroxylase (hydroxylase) deficiencies. Endocrine Reviews 33 SAT-256.

Adamski J, Normand T, Leenders F, Monte D, Begue A, Stehelin D, Jungblut PW \& de Launoit Y 1995 Molecular cloning of a novel widely expressed human $80 \mathrm{kDa} 17 \beta$-hydroxysteroid dehydrogenase IV. Biochemical Journal 311 437-443.

Adeniji A, Twenter BM, Byrns MC, Jin Y, Chen M, Winkler JD \& Penning TM 2012 Development of potent and selective inhibitors of aldo-keto reductase 1C3 (type 5 17 $\beta$-hydroxysteroid dehydrogenase) based on $N$-phenyl-aminobenzoates and their structure-activity relationships. Journal of Medicinal Chemistry 55 2311-2323. (doi:10.1021/jm201547v)

Andersson S, Geissler WM, Patel S \& Wu L 1995 The molecular biology of androgenic 17 $\beta$-hydroxysteroid dehydrogenases. Journal of Steroid Biochemistry and Molecular Biology 53 37-39. (doi:10.1016/09600760(95)00039-3)

Andriole G, Bostwick DG, Brawley OW, Gomella LG, Marberger M, Montorsi F, Pettaway CA, Tammela TL, Teloken C, Tindall DJ et al. 2010 REDUCE Study Group. Effect of dutasteride on the risk of prostate cancer. New England Journal of Medicine 362 1192-1202. (doi:10.1056/ NEJMoa0908127) 
Astellas Pharmaceuticals J 2013 Phase I/II Study of ASP9521 in CastrateResistant Prostate Cancer (CRPC) Patients. Clinical Trials.gov NCT013522082013 http://clinicaltrials.gov/show/NCT013522082013.

Attard G, Reid AH, Olmos D \& de Bono JS 2009 Antitumor activity with CYP17 blockade indicates that castration-resistant prostate cancer frequently remains hormone driven. Cancer Research 69 4937-4940. (doi:10.1158/0008-5472.CAN-08-4531)

Attard G, Reid AH, Auchus RJ, Hughes BA, Cassidy AM, Thompson E, Oommen NB, Folkerd E, Dowsett M, Arlt W et al. 2012 Clinical and biochemical consequences of CYP17A1 inhibition with abiraterone given with and without exogenous glucocorticoids in castrate men with advanced prostate cancer. Journal of Clinical Endocrinology and Metabolism 97 507-516. (doi:10.1210/jc.2011-2189)

Auchus RJ 2004 The backdoor pathway to dihydrotestosterone. Trends in Endocrinology and Metabolism 15 432-438. (doi:10.1016/j.tem.2004. 09.004)

Auchus RJ \& Miller WL 2012 Defects in androgen biosynthesis causing 46,XY disorders of sexual development. Seminars in Reproductive Medicine 30 417-426. (doi:10.1055/s-0032-1324726)

Bartsch G, Rittmaster RS \& Klocker H 2002 Dihydrotestosterone and the concept of $5 \alpha$-reductase inhibition in human benign prostatic hyperplasia. World Journal of Urology 19 413-425. (doi:10.1007/ s00345-002-0248-5)

Bauman DR, Steckelbroeck S, Peehl DM \& Penning TM 2006a Transcript profiling of the androgen signal in normal prostate, benign prostatic hyperplasia, and prostate cancer. Endocrinology 147 5806-5816. (doi:10.1210/en.2006-0627)

Bauman D, Steckelbroeck S, Williams MV, Peehl DM \& Penning TM $2006 b$ Identification of the major oxidative $3 \alpha$-hydroxysteroid dehydrogenase in human prostate that converts $5 \alpha$-andostane- $3 \alpha, 17 \beta$-diol to $5 \alpha$ dihydrotestosterone. A potential therapeutic target for androgen dependent disease. Molecular Endocrinology 20 444-458. (doi:10.1210/ me.2005-0287)

Bruno R, Gover TD, Burger AM, Brodie AM \& Njar VC 2008 $17 \alpha$-Hydroxylase/17,20 lyase inhibitor VN/124-1 inhibits growth of androgen-independent prostate cancer cells via induction of the endoplasmic reticulum stress response. Molecular Cancer Therapeutics 7 2828-2836. (doi:10.1158/1535-7163.MCT-08-0336)

Bull H, Garcia-Carlo M, Andersson S, Baginsky WF, Chan K, Ellsworth DE, Miller RR, Stearns RA, Bakshi RK, Rasmusson GH et al. 1996 Mechanism-based inhibition of human steroid $5 \alpha$-reductase by finasteride: enzyme catalyzed formation of NADP-dihydrofinasteride, a potent bisubstrate analog inhibitor. Journal of the American Chemical Society 118 2359-2365. (doi:10.1021/ja953069t)

Byrns M, Jin Y \& Penning TM 2011 Inhibitors of type $517 \beta$-hydroxysteroid dehydrogenase (AKR1C3): overview and structural insights. Journal of Steroid Biochemistry and Molecular Biology 125 95-104. (doi:10.1016/ j.jsbmb.2010.11.004)

Byrns M, Mindnich R, Duan L \& Penning TM 2012 Overexpression of aldo-keto reductase 1C3 (AKR1C3) in LNCaP cells diverts androgen metabolism towards testosterone resulting in resistance to the $5 \alpha$-reductase inhibitor finasteride. Journal of Steroid Biochemistry and Molecular Biology 130 7-15. (doi:10.1016/j.jsbmb.2011.12.012)

Cai C, Chen S, Ng P, Bubley GJ, Nelson PS, Mostaghel EA, Marck B, Matsumoto AM, Simon NI, Wang H et al. 2011 Intratumoral de novo steroid synthesis activates androgen receptor in castration-resistant prostate cancer and is upregulated by treatment with CYP17A1 inhibitors. Cancer Research 71 6503-6513. (doi:10.1158/0008-5472. CAN-11-0532)

Cantagrel V, Lefeber DJ, Ng BG, Guan Z, Silhavy JL, Bielas SL, Lehle L, Hombauer H, Adamowicz M, Swiezewska E et al. 2010 SRD5A3 is required for converting polyprenol to dolichol and is mutated in a congenital glycosylation disorder. Cell 142 203-217. (doi:10.1016/ j.cell.2010.06.001)

Carstensen JF, Tesdorpf JG, Kaufmann M, Markus MM, Husen B, Leenders F, Jakob F, de Launoit Y \& Adamski J 1996 Characterization of 17 $\beta$-hydroxysteroid dehydrogenase IV. Journal of Endocrinology 150 (Suppl) S3-12. (doi:10.1677/joe.0.150S003)

Castagnetta LA, Carruba G, Traina A, Granata OM, Markus M, Pavone-Macaluso M, Blomquist CH \& Adamski J 1997 Expression of different $17 \beta$-hydroxysteroid dehydrogenase types and their activities in human prostate cancer cells. Endocrinology 138 4876-4882. (doi:10.1210/endo.138.11.5497)

Chang K-H, Li R, Papari-Zareei M, Watumull L, Zhao YD, Auchus RJ \& Sharifi N 2011 Dihydrotestosterone synthesis bypasses testosterone to drive castration-resistant prostate cancer. PNAS 108 13728-13733. (doi:10.1073/pnas.1107898108)

Chang K-H, Li R, Kuri B, Lotan Y, Roehrborn CG, Liu J, Vessella R, Nelson R, Kapur P, Guo X et al. 2013 A gain-of-function mutation in DHT synthesis in castration-resistant prostate cancer. Cell 154 1074-1084. (doi:10.1016/j.cell.2013.07.029)

Chen M, Adeniji AO, Twenter BM, Winkler JD, Christianson DW \& Penning TM 2012 Crystal structures of AKR1C3 containing an $\mathrm{N}$-(aryl)amino-benzoate inhibitor and a bifunctional AKR1C3 inhibitor and androgen receptor antagonist. Therapeutic leads for castrate resistant prostate cancer. Bioorganic and Medicinal Chemistry Letters 22 3492-3497. (doi:10.1016/j.bmcl.2012.03.085)

Chung BC, Picado-Leonard J, Haniu M, Bienkowski M, Hall PF, Shively JE \& Miller WL 1987 Cytochrome P450c17 (steroid $17 \alpha$-hydroxylase/17,20 lyase): cloning of human adrenal and testis cDNAs indicates the same gene is expressed in both tissues. PNAS $\mathbf{8 4} 407-411$. (doi:10.1073/ pnas.84.2.407)

Day J, Tutill HJ, Foster PA, Bailey HV, Heaton WB, Sharland CM, Vicker N, Potter BV, Purohit A \& Reed MJ 2009 Development of hormonedependent prostate cancer models for the evaluation of inhibitors of $17 \beta$-hydroxysteroid dehydrogenase type 3. Molecular and Cellular Endocrinology 301 251-258. (doi:10.1016/j.mce.2008.08.014)

DeVore NM \& Scott EE 2012 Structures of cytochrome P450 17A1 with prostate cancer drugs abiraterone and TOK-001. Nature 482 116-119. (doi:10.1038/nature10743)

Flanagan JU, Yosaatmadja Y, Teague RM, Chai MZ, Turnbull AP \& Squire CJ 2012 Crystal structures of three classes of non-steroidal antiinflammatory drugs in complex with aldo-keto reductase 1C3. PLoS ONE 7 e43965. (doi:10.1371/journal.pone.0043965)

Fluck C, Meyer-Boni M, Pandey AV, Kempna P, Miller WL, Schoenle EJ \& Biason-Lauber A 2011 Why boys will be boys: two pathways of fetal testicular androgen biosynthesis are needed for male sexual differentiation. American Journal of Human Genetics 89 201-218. (doi:10.1016/ j.ajhg.2011.06.009)

Frye SV 2006 Discovery and clinical development of dutasteride, a potent dual $5 \alpha$-reductase inhibitor. Current Topics in Medicinal Chemistry 6 405-421. (doi:10.2174/156802606776743101)

Fung K-M, Shea-Samara EH, Wong C, Krin R, Jones AM, Bane B, Liu CZ, Yang JT, Pitha JV, Culkin DJ et al. 2006 Increased expression of type 2 $3 \alpha$-hydroxysteroid dehydrogenase/type $517 \beta$-hydroxysteroid dehydrogenase (AKR1C3) and its relationship with the androgen receptor in prostate carcinoma. Endocrine-Related Cancer 13 169-180. (doi:10.1677/erc.1.01048)

Geissler WM, Davis DL, Wu L, Bradshaw KD, Patel S, Mendonca BB, Elliston KO, Wilson JD, Russell DW \& Andersson S 1994 Male pseudohermaphroditism caused by mutations of testicular $17 \beta$-hydroxysteroid dehydrogenase 3. Nature Genetics 7 34-39. (doi:10.1038/ng0594-34)

Grosse L, Pâquet S, Caron P, Fazli L, Rennie PS, Bélanger A \& Barbier O 2013 Androgen glucuronidation: an unexpected target for androgen deprivation therapy, with prognosis and diagnostic implications. Cancer Research 73 6963-6971. (doi:10.1158/0008-5472.CAN-13-1462)

Guerini V, Sau D, Scaccianoce E, Rusmini P, Ciana P, Maggi A, Martini PG, Katzenellenbogen BS, Martini L, Motta M et al. 2005 The androgen derivative $5 \alpha$-androstane- $3 \beta, 17 \beta$-diol inhibits prostate cancer cell migration through activation of the estrogen receptor $\beta$ subtype. Cancer Research 65 5445-5453. (doi:10.1158/0008-5472.CAN-04-1941) http://erc.endocrinology-journals.org DOI: 10.1530/ERC-14-0109
(C) 2014 Society for Endocrinology Printed in Great Britain 
Guillemette C, Lévesque E, Beaulieu M, Turgeon D, Hum DW \& Bélanger A 1997 Differential regulation of two uridine diphospho-glucuronosyltransferases, UGT2B15 and UGT2B17, in human prostate LNCaP cells. Endocrinology 138 2998-3005. (doi:10.1210/endo.138.7.5226)

Hamid A, Pfeiffer MJ, Verhaegh GW, Schaafsma E, Brandt A, Sweep FC, Sedelaar JP \& Schalken JA 2012 Aldo-keto reductase family 1 member C3 (AKR1C3) is a biomarker and therapeutic target for castrationresistant prostate cancer. Molecular Medicine 18 1449-1455. (doi:10.2119/molmed.2012.00296)

Higashi T, Yamauchi A, Shimada K, Koh E, Mizokami A \& Namiki M 2005 Determination of prostatic androgens in $10 \mathrm{mg}$ of tissue using liquid chromatography-tandem mass spectrometry with charged derivatization. Analytical and Bioanalytical Chemistry 382 1035-1043. (doi:10.1007/s00216-005-3233-1)

Higashi T, Takayama N, Kyutoku M, Shimada K, Koh E \& Namiki M 2006 Liquid chromatography-mass spectrometric assay of androstenediol in prostatic tissue: influence of androgen deprivation therapy on its level. Steroids 71 1007-1013. (doi:10.1016/j.steroids.2006.08.003)

Hofland J, van Weerden WM, Dits NF, Steenbergen J, van Leenders GJ, Jenster G, Schröder FH \& de Jong FH 2010 Evidence of limited contributions for intratumoral steroidogenesis in prostate cancer. Cancer Research 70 1256-1264. (doi:10.1158/0008-5472.CAN-09-2092)

Hu R, Lu C, Mostaghel EA, Yegnasubramanian S, Gurel M, Tannahill C, Edwards J, Isaacs WB, Nelson PS, Bluemn E et al. 2012 Distinct transcriptional programs mediated by the ligand-dependent full-length androgen receptor and its splice variants in castration-resistant prostate cancer. Cancer Research 72 3457-3462. (doi:10.1158/0008-5472. CAN-11-3892)

Huggins CB 1965 Two principles in endocrine therapy of cancers: hormone deprival and hormone interference. Cancer Research $\mathbf{2 5}$ $1163-1167$

Huggins CB \& Hodges CV 1941 Studies on prostatic cancer 1. Effect of castration, estrogen and androgen injection on serum phosphatases in metastatic carcinoma of the prostate. Cancer Research $1293-397$.

Jin Y \& Penning TM 2006 Multiple steps determine the overall rate of the reduction of $5 \alpha$-dihydrotestosterone catalyzed by human type $33 \alpha$-hydroxysteroid dehydrogenase: implications for the elimination of androgens. Biochemistry 45 13054-13063. (doi:10.1021/bi060591r)

Jin Y, Stayrook SE, Albert RH, Palackal NT, Penning TM \& Lewis M 2001 Crystal structure of human type III $3 \alpha$-hydroxysteroid dehydrogenase/bile acid binding protein complexed with $\mathrm{NADP}^{+}$and ursodeoxycholate. Biochemistry 40 10161-10168. (doi:10.1021/ bi010919a)

Kennealey GT \& Furr BJ 1991 Use of the nonsteroidal anti-androgen Casodex in advanced prostatic carcinoma. Urologic Clinics of North America 18 99-110.

Knudsen K \& Penning TM 2010 Partners in crime: deregulation of AR activity and androgen synthesis in prostate cancer. Trends in Endocrinology and Metabolism 21 315-324. (doi:10.1016/j.tem. 2010.01.002)

Labrie F, Simard J, Luu-The V, Pelletier G, Belanger A, Lachance Y, Zhao HF, Labrie C, Breton N, de Launoit Y et al. 1992 Structure and tissue-specific expression of $3 \beta$-hydroxysteroid dehydrogenase/5-ene-4-ene isomerase genes in human and rat classical and peripheral steroidogenic tissues. Journal of Steroid Biochemistry and Molecular Biology 41 421-435. (doi:10.1016/0960-0760(92)90368-S)

Lachance Y, Luu-The V, Labrie C, Simard J, Dumont M, de Launoit Y, Guerin S, Leblanc G \& Labrie F 1992 Characterization of human $3 \beta$-hydroxysteroid dehydrogenase $/ \Delta^{5}-\Delta^{4}$-isomerase gene and its expression in mammalian cells. Journal of Biological Chemistry 2673551.

Levy MA, Brandt M, Sheedy KM, Dinh JT, Holt DA, Garrison LM, Bergsma DJ \& Metcalf BW 1994 Epristeride is a selective and specific uncompetitive inhibitor of human steroid $5 \alpha$-reductase isoform 2 . Journal of Steroid Biochemistry and Molecular Biology 48 197-206. (doi:10.1016/0960-0760(94)90145-7)
Li R, Evaul K, Sharma KK, Chang KH, Yoshimoto J, Liu J, Auchus RJ \& Sharifi N 2012 Abiraterone inhibits 3ß-hydroxysteroid dehydrogenase: a rationale for increasing drug exposure in castration-resistant prostate cancer. Clinical Cancer Research 18 3571-3579. (doi:10.1158/10780432.CCR-12-0908)

Liedtke AJ, Adeniji AO, Chen M, Byrns MC, Jin Y, Christianson DW, Marnett LJ \& Penning TM 2013 Development of potent and selective indomethacin analogues for the inhibition of AKR1C3 (type 5 17ß-hydroxysteroid dehydrogenase/prostaglandin F synthase) in castrate-resistant prostate cancer. Journal of Medicinal Chemistry $\mathbf{5 6}$ 2429-2446. (doi:10.1021/jm3017656)

Lin H-K, Jez JM, Schlegel BP, Peehl DM, Pachter JA \& Penning TM 1997 Expression and characterization of recombinant type $23 \alpha$-hydroxysteroid dehydrogenase (HSD) from human prostate: demonstration of bifunctional $3 \alpha / 17 \beta$-HSD activity and cellular distribution. Molecular Endocrinology 11 1971-1984. (doi:10.1210/mend.11.13.0026)

Lin HK, Steckelbroeck S, Fung KM, Jones AN \& Penning TM 2004 Characterization of a monoclonal antibody for human aldo-keto reductase AKR1C3 (type $23 \alpha$-hydroxysteroid dehydrogenase/type 5 $17 \beta$-hydroxysteroid dehydrogenase); immunohistochemical detection in breast and prostate. Steroids 69 795-801. (doi:10.1016/j.steroids. 2004.09.014)

Loriot Y, Fizazi K, Jones RJ, Van den Brande J, Molife RL, Omlin A, James ND, Baskin-Bey E, Heeringa M, Baron B et al. 2014 Safety, tolerability and anti-tumor activity of the androgen biosynthesis inhibitor ASP9521 in patients with metastatic castration-resistant prostate cancer: multi-centre phase I/II study. Investigational New Drugs (In Press). (doi:10.1007/s10637-014-0101-x)

Lovering AL, Ride JP, Bunce CM, Desmond JC, Cummings SM \& White SA 2004 Crystal structures of prostaglandin $\mathrm{D}_{2}$ 11-ketoreductase (AKR1C3) in complex with the nonsteroidal anti-inflammatory drugs flufenamic acid and indomethacin. Cancer Research 64 1802-1810. (doi:10.1158/ 0008-5472.CAN-03-2847)

Luu The V, Lachance Y, Labrie C, Leblanc G, Thomas JL, Strickler RC \& Labrie F 1989 Full length cDNA structure and deduced amino acid sequence of human $3 \beta$-hydroxy-5-ene steroid dehydrogenase. Molecular Endocrinology 3 1310-1312. (doi:10.1210/mend-3-8-1310)

Mitsiades N, Sung CC, Schultz N, Danila DC, He B, Eedunuri VK, Fleisher M, Sander C, Sawyers CL \& Scher HI 2012 Distinct patterns of dysregulated expression of enzymes involved in androgen synthesis and metabolism in metastatic prostate cancer tumors. Cancer Research 72 6142-6152. (doi:10.1158/0008-5472.CAN-12-1335)

Mohler JL, Titus MA \& Wilson EM 2011 Potential prostate cancer drug target: bioactivation of androstanediol by conversion to dihydrotestosterone. Clinical Cancer Research 17 5844-5849. (doi:10.1158/ 1078-0432.CCR-11-0644)

Montgomery RB, Mostaghel EA, Vessella R, Hess DL, Kalhorn TF, Higian CS, True LD \& Nelson PS 2008 Maintenance of intratumoral androgens in metastatic prostate cancer: a mechanism for castration-resistant tumor growth. Cancer Research 68 4447-4454. (doi:10.1158/0008-5472.CAN08-0249)

Mostaghel EA, March BT, Plymate SR, Vessella RL, Balk S, Mastsumoto AM, Nelson PS \& Montgomery RB 2011 Resistance to CYP17A1 inhibition with abiraterone in castrate-resistance prostate cancer: induction of steroidogenesis and androgen receptor splice variants. Clinical Cancer Research 17 5913-5925. (doi:10.1158/1078-0432.CCR11-0728)

Nadeau G, Bellemare J, Audet-Walsh É, Flageole C, Huang SP, Bao BY, Douville P, Caron P, Fradet Y, Lacombe L et al. 2011 Deletions of the androgen-metabolizing $U G T 2 B$ genes have an effect on circulating steroid levels and biochemical recurrence after radical prostatectomy in localized prostate cancer. Journal of Clinical Endocrinology and Metabolism 96 1550-1557. (doi:10.1210/jc.2011-1049)

Nakajin S \& Hall PF 1981 Microsomal cytochrome P-450 from neonatal pig testis. Purification and properties of a C21 steroid side-chain cleavage 
system (17 $\alpha$-hydroxylase-C17,20 lyase). Journal of Biological Chemistry 256 3871-3876.

Nakajin S, Shively JE, Yuan PM \& Hall PF 1981 Microsomal cytochrome P-450 from neonatal pig testis: two enzymatic activities $(17 \alpha-$ hydroxylase and c17,20-lyase) associated with one protein. Biochemistry 20 4037-4042. (doi:10.1021/bi00517a014)

Njar VC \& Brodie AM 1999 Inhibitors of 17 $\alpha$-hydroxylase/17,20-lyase (CYP17): potential agents for the treatment of prostate cancer. Current Pharmaceutical Design 5 163-180.

Penning TM, Burczynski ME, Jez JM, Hung C-F, Lin H-K, Ma H, Moore M, Palackal N \& Ratnam K 2000 Human $3 \alpha$-hydroxysteroid dehydrogenase isoforms (AKR1C1-AKR1C4) of the aldo keto reductase superfamily: functional plasticity and tissue distribution reveals roles in the inactivation and formation of male and female sex hormones. Biochemical Journal 351 67-77. (doi:10.1042/02646021:3510067)

Pfeiffer MJ, Smit FP, Sedelaar JP \& Schalken JA 2011 Steroidogenic enzymes and stem cell markers are upregulated during androgen deprivation in prostate cancer. Molecular Medicine 17 657-664. (doi:10.2119/molmed. 2010.00143)

Purohit A, Williams GJ, Howarth NM, Potter BV \& Reed MJ 1995 Inactivation of steroid sulfatase by an active site-directed inhibitor, estrone-3-O-sulfamate. Biochemistry 34 11508-11514. (doi:10.1021/ bi00036a025)

Purohit A, Woo LW, Singh A, Winterborn CJ, Potter BV \& Reed MJ 1996 In vivo activity of 4-methylcoumarin-7-O-sulfamate, a nonsteroidal, nonestrogenic steroid sulfatase inhibitor. Cancer Research 56 4950-4955.

Rheaume E, Lachance Y, Zhao HF, Breton N, Dumont M, de Launoit Y, Trudel C, Luu-The V, Simard J \& Labrie F 1991 Structure and expression of a new complementary DNA encoding the almost exclusive 3 $\beta$-hydroxysteroid dehydrogenase $/ \Delta^{5}-\Delta^{4}$-isomerase in human adrenals and gonads. Molecular Endocrinology 5 1147-1157. (doi:10.1210/mend5-8-1147)

Rheaume E, Simard J, Morel Y, Mebarki F, Zachmann M, Forest MG, New MI \& Labrie F 1992 Congenital adrenal hyperplasia due to point mutations in the type II $3 \beta$-hydroxysteroid dehydrogenase gene. Nature Genetics $\mathbf{1}$ 239-245. (doi:10.1038/ng0792-239)

Rheaume E, Sanchez R, Simard J, Chang YT, Wang J, Pang S \& Labrie F 1994 Molecular basis of congenital adrenal hyperplasia in two siblings with classical nonsalt-losing $3 \beta$-hydroxysteroid dehydrogenase deficiency. Journal of Clinical Endocrinology and Metabolism 79 1012-1018. (doi:10.1210/jcem.79.4.7962268)

Rizner TL \& Penning TM 2013 Role of aldo-keto reductase family 1 (AKR1) enzymes in human steroid metabolism. Steroids 79 49-63. (doi:10.1016/j.steroids.2013.10.012)

Rizner TL, Lin HK, Peehl DM, Steckelbroeck S, Bauman DR \& Penning TM 2003 Human type $33 \alpha$-hydroxysteroid dehydrogenase (aldo-keto reductase $1 \mathrm{C} 2$ ) and androgen metabolism in prostate cells. Endocrinology 144 2922-2932. (doi:10.1210/en.2002-0032)

Russell DW \& Wilson JD 1994 Steroid $5 \alpha$-reductase: two genes/two enzymes. Annual Review of Biochemistry 63 25-61. (doi:10.1146/ annurev.bi.63.070194.000325)

Scher HI, Beer TM, Higano CS, Anand A, Taplin ME, Efstathiou E, Rathkopf D, Shelkey J, Yu EY, Alumkal J et al. 2010 Antitumour activity of MDV3100 in castration-resistant prostate cancer: a phase 1-2 study. Lancet 375 1437-1446. (doi:10.1016/S01406736(10)60172-9)

Scher HI, Fizazi K, Saad F, Taplin ME, Sternberg CN, Miller K, de Wit R, Mulders P, Chi KN, Shore ND et al. 2012 Increased survival with enzalutamide in prostate cancer after chemotherapy. New England Journal of Medicine 367 1187-1197. (doi:10.1056/ NEJMoa1207506)

Shapiro LJ 1979 Steroid sulfatase deficiency and X-linked ichthyosis. Clinical Biochemistry 12 205. (doi:10.1016/S0009-9120(79)80096-X)

http://erc.endocrinology-journals.org DOI: 10.1530/ERC-14-0109
(C) 2014 Society for Endocrinology Printed in Great Britain
Shapiro LJ 1985 Steroid sulfatase deficiency and the genetics of the short arm of the human X chromosome. Advances in Human Genetics 14 331-381. (doi:10.1007/978-1-4615-9400-0_5)

Sharifi R, Bruskewitz RC, Gittleman MC, Graham SD Jr, Hudson PB \& Stein B 1996 Leuprolide acetate $22.5 \mathrm{mg}$ 12-week depot formulation in the treatment of patients with advanced prostate cancer. Clinical Therapeutics 18 647-657. (doi:10.1016/S0149-2918(96)80215-3)

Shaw G, Fenelon J, Sichlau M, Auchus RJ, Wilson JD \& Renfree MB 2006 Role of the alternate pathway of dihydrotestosterone formation in virilization of the Wolffian ducts of the tammar wallaby, Macropus eugenii. Endocrinology 147 2368-2373. (doi:10.1210/en.2005-1251)

Stanbrough M, Bubley GJ, Ross K, Golub TR, Rubin MA, Penning TM, Febbo PG \& Balk SP 2006 Increased expression of genes converting adrenal androgens to testosterone in androgen-independent prostate cancer. Cancer Research 66 2815-2825. (doi:10.1158/0008-5472.CAN-05-4000)

Steckelbroeck S, Jin Y, Gopishetty S, Oyesanmi B \& Penning TM 2004 Human cytosolic $3 \alpha$-hydroxysteroid dehydrogenases of the aldo-keto reductase superfamily display significant $3 \beta$-hydroxysteroid dehydrogenase activity: implications for steroid hormone metabolism and action. Journal of Biological Chemistry 279 10784-10795. (doi:10.1074/ jbc.M313308200)

Tamae D, Byrns M, Marck B, Mostaghel EA, Nelson PS, Lange P, Lin D, Taplin ME, Balk S, Ellis W et al. 2013 Development, validation and application of a stable isotope dilution liquid chromatography electrospray ionization/selected reaction monitoring/mass spectrometry (SID-LC/ESI/SRM/MS) method for quantification of keto-androgens in human serum. Journal of Steroid Biochemistry and Molecular Biology 138C 281-289. (doi:10.1016/j.jsbmb.2013.06.014)

Taplin M-E, Montgomery B, Logothetis CJ, Bubley GJ, Richie JP, Dalkin BL, Sanda MG, Davis JW, Loda M, True LD et al. 2014 Intense androgendeprivation therapy with abiraterone acetate plus leuprolide acetate in patients with localized high-risk prostate cancer: results of a randomized phase II neoadjuvant study. Journal of Clinical Oncology [in press].

Thomas JL, Mason JI, Brandt S, Spencer BR Jr \& Norris W $2002 a$ Structure/function relationships responsible for the kinetic differences between human type 1 and type $23 \beta$-hydroxysteroid dehydrogenase and for the catalysis of the type 1 activity. Journal of Biological Chemistry 277 42795-42801. (doi:10.1074/jbc.M208537200)

Thomas JL, Mason JI, Brandt S \& Norris W 2002b Differences in substrate and inhibitor kinetics of human type 1 and type $23 \beta$-hydroxysteroid dehydrogenase are explained by the type 1 mutant, H156Y. Endocrine Research 28 471-475. (doi:10.1081/ERC-120016825)

Thomas JL, Mack VL, Glow JA, Moshkelani D, Terrell JR \& Bucholtz KM 2008 Structure/function of the inhibition of human $3 \beta$-hydroxysteroid dehydrogenase type 1 and type 2 by trilostane. Journal of Steroid Biochemistry and Molecular Biology 111 66-73. (doi:10.1016/j.jsbmb. 2008.04.007)

Thompson I, Goodman PJ, Tangen CM, Lucia MS, Miller GJ, Ford LG, Lieber MM, Cespedes RD, Atkins JN, Lippman SM et al. 2003 The influence of finasteride on the development of prostate cancer. New England Journal of Medicine 349 215-224. (doi:10.1056/ NEJMoa030660)

Titus MA, Li Y, Kozyreva OG, Maher V, Godoy A, Smith GJ \& Mohler JL $20145 \alpha$-reductase type 3 enzyme in benign and malignant prostate. Prostate 74 235-249. (doi:10.1002/pros.22745)

Tran C, Ouk S, Clegg NJ, Chen Y, Watson PA, Arora V, Wongvipat J, Smith-Jones PM, Yoo D, Kwon A et al. 2009 Development of a secondgeneration antiandrogen for treatment of advanced prostate cancer. Science 324 787-790. (doi:10.1126/science.1168175)

Uemura M, Tamura K, Chung S, Honma S, Okuyama A, Nakamura Y \& Nakagawa H 2008 Novel $5 \alpha$-steroid reductase (SRD5A3, type-3) is overexpressed in hormone-refractory prostate cancer. Cancer Science 99 81-86. (doi:10.1111/j.1349-7006.2007.00656.x)

U.S. Food and Drug Administration 2011 FDA Drug Safety Communication: 5-alpha reductase inhibitors (5-ARIs) may increase the risk of 
a more serious form of prostate cancer. (http://www.fda.gov/drugs/ drugsafety/ucm 258314.htm)

Vasaitis T, Belosay A, Schayowitz A, Khandelwal A, Chopra P, Gediya LK, Guo Z, Fang HB, Njar VC \& Brodie AM 2008 Androgen receptor inactivation contributes to antitumor efficacy of $17 \alpha$-hydroxylase/17, 20-lyase inhibitor 3ß-hydroxy-17-(1H-benzimidazole-1-yl)androsta-5, 16-diene in prostate cancer. Molecular Cancer Therapeutics 7 2348-2357. (doi:10.1158/1535-7163.MCT-08-0230)

Vicker N, Sharland CM, Heaton WB, Gonzalez AM, Bailey HV, Smith A, Springall JS, Day JM, Tutill HJ, Reed MJ et al. 2009 The design of novel $17 \beta$-hydroxysteroid dehydrogenase type 3 inhibitors. Molecular and Cellular Endocrinology 301 259-265. (doi:10.1016/ j.mce.2008.08.005)

Watanabe K, Kakefuda A, Yasuda M, Enjo K, Kikuchi A, Furutani T, Naritomi Y, Otsuka Y, Okada M \& Ohta M 2013 Discovery of 2-methyl1-\{1-[(5-methyl-1H-indol-2-yl)carbonyl]piperidin-4-yl\}propan-2-ol: a novel, potent and selective type $517 \beta$-hydroxysteroid dehydrogenase inhibitor. Bioorganic and Medicinal Chemistry 21 5261-5270. (doi:10.1016/j.bmc.2013.06.025)

Wilson JD, Auchus RJ, Leihy MW, Guryev OL, Estabrook RW, Osborn SM, Shaw G \& Renfree MB $20035 \alpha$-androstane- $3 \alpha, 17 \beta$-diol is formed in tammar wallaby pouch young testes by a pathway involving $5 \alpha$-pregnane-3 $\alpha, 17 \alpha$-diol-20-one as a key intermediate. Endocrinology 144 575-580. (doi:10.1210/en.2002-220721)

Yen PH, Allen E, Marsh B, Mohandas T, Wang N, Taggart RT \& Shapiro LJ 1987 Cloning and expression of steroid sulfatase cDNA and the frequent occurrence of deletions in STS deficiency: implications for X-Y interchange. Cell 49 443-454. (doi:10.1016/0092-8674(87) 90447-8)

Yepuru M, Wu Z, Kyulkarni A, Yin F, Barrett CM, Kim J, Steiner MS, Miller DD, Dalton JT \& Narayanan R 2013 Steroidogenic enzyme AKR1C3 is a novel androgen receptor-selective coactivator that promotes prostate cancer growth. Clinical Cancer Research 19 5613-5625. (doi:10.1158/ 1078-0432.CCR-13-1151)

Received in final form 3 May 2014

Accepted 14 May 2014

Made available online as an Accepted Preprint

14 May 2014
(C) 2014 Society for Endocrinology Printed in Great Britain
Published by Bioscientifica Ltd. 